\title{
THE ROMAN COLONIZATION OF BRITAIN: TWO POETIC INSIGHTS
}

\author{
C Mann (Rhodes University)
}

\section{DISPOSSESSING BRITAIN}

The poem draws on different translations of the description of the Battle of Mons Graupius by Tacitus the Roman historian. The account is found in Agricola, the eponymous biography of Julia's father, Gnaeus Julius Agricola, a Gallo-Roman military commander, pontiff and governor of Britannia. The battle took place in northern Britain in AD 83. Tacitus depicts the battle as ending resistance to the Roman conquest of Britain.

Keywords: Tacitus; Julia; Battle of Mons Graupius; Agricola; Roman colonialism; colonization of Britain; post-colonial literature; translation.

\section{Artefact Codex 2374.1}

Text in the hand of Julia, wife of Tacitus the historian and daughter of Agricola the general, on waxed wooden tablets c. AD 94.

Julia to Tacitus in Rome, greetings.

Please hurry back,

He weakens with every day.

Last night he lay awake for hours,

Clutching my hand if I stood to leave.

He kept on telling me things

We hadn't heard before,

Blurted out and left in disarray

Like shards of that Etruscan vase of his

Scattered across the floor.

I've done the best I can

To sweep them up

And piece them together.

Candidus greets you.

He's offered us a slave, a cook from Gaul.

Claudia's learnt how to count to ten.

She has a little gift for you.

Farewell, my dearest one.

May there be no ravens in the skies

To thwart your swift return. 


\section{Artefact Codex 2374.3}

'Keeps coming back', he said, 'I'm up on a ridge, rocks, trees, Helmets, horses, creaking leather,

Rebel army in the valley below'.

'But no, wait - before I forget, Festus owes us money. A lot.

Write to his steward in Mantua. Ask for the figures. Don't back off.

'Anyway - mist, early morning mist, Drifting across green fields below.

Come on, you can put this better, War roughens a soldier's speech'.

\section{Artefact Codex 2374.4}

As dawn-light spread, bronze-breastplated Jupiter, Hurrying north to guide Rome's swords and shields, Concealed himself inside a wraith of mist That drifted over hedges, farms and fields.

The thunderbolts of fate held in his hand, the wrath of ............

(Illegible. Wax abraded by unknown objects).

Artefact Codex 2374.6

Galgacus their leader, I was told, In private, by one of our friends, Leapt on a cart, sword in hand, And started to work up his men.

But don't trust informers. Ever. Tell Tacitus. After they've gone, Ponder the mind behind the mosaic, The bag of silver tucked in the hay. 
'Freedom!' he yelled, 'Today at last

Britain will once more be free!'

At which the mob in the farmyard

Shouted and chanted songs of war.

'Slavery', he shouted, 'isn't our way!'

Must we forever allow our kinsmen

To be torn from their ancestors

And sent in chains to other lands?

'Day after day, insulted, whipped,

Our people are exhausted by the toil

Of draining marshes, felling woods,

Building roads and hewing mines.

'Who for? I ask. Maggots in Rome?

For traitorous chieftains in our midst, Snickering on about progress in Latin, Selling off land and feeding the forts?'

'Does paying their tax, their corn levies, Bring any release? Thieves of the world, The Romans give the name of empire

To slaughter, slavery and looting'.

'When they've laid waste a countryside, Burning the farms and villages, And murdering all who try to resist, They call that devastation peace'.

'Our Druids, by prayer and sacrifice, Have built a fence around us all. Each soul that bravely fights today Will surely reach heaven unharmed'.

\section{Artefact Codex 2374.10}

Agricola, last night, coughing, A towel steaming on his chest. 'Get this down,' he says. Talks, Coughs, then slumps, eyes shut. 
'Where was I? It's all too much.

I can't explain. Where's the bleeder,

The Greek one? My temples, aaah!

Feel here, the vein keeps throbbing.

'The meadows, later, a hideous sight.

Spears, helmets, corpses, everywhere.

Dead eyes still staring, twisted bodies

Groaning on grass moist with blood.

'A few men walked round aimlessly.

Others sat on the ground, speechless.

I saw a young woman next to a hedge

Fall to her knees by a body and scream.

'Next day, the valley was forsaken.

The silence of desolation reigned.

Far off, above the hills of Britain,

The smoke of burning farms and villages

'Plumed quietly into the morning sky

As groups of hostages ..........

Our cavalry ... ... few losses ......'

(Illegible. Wood dark, rotted by moisture.)

\section{SAYING GOODBYE TO THE ROMANS}

Some 380 years after the battle of Mons Graupius, Roman withdrawal from the province of Brittannia was underway. This poem is set in 410, when Constantine 111 moved the last remaining legion out of Britain to confront uprisings in Gaul. The speaker is Ethelbert, a fictional clan leader.

Keywords: Roman withdrawal from Britain; decolonization; post-colonial literature.

i

The day the Romans left they marched their soldiers to the ships drawn up along the shore. 
A crowd soon gathered on the beach and cursed them as they passed.

Some hotheads daubed their cheeks with streaks of mud and purple dye, looted the mead stored in the feasting halls and hanged a few collaborators in the woods.

That was, I suppose, to be expected.

After so many years of Roman oppression it could have been worse, much worse.

It was in fact, as you'd expect, so exhilarating, so indescribably exhilarating to be free!

No longer paying tax to foreigners, powerless to stop the worst of their merchants enticing young girls behind the haystacks with figs from Syria and wine from Gaul.

No longer fearful of their swaggering troops torturing the dissidents in the forts, before the new proconsul did his rounds and told them to lay off the beatings for a while and try a little winning hearts and minds.

And then, of course, no more cringing in front of magistrates and engineers who'd take such pleasure, such jovial pleasure in asking how many of us could read or write or build a level road before they came.

As if our worth, our stature as a people could ever be judged by such things!

Good riddance to their arrogance I say were we not happier, and more humane before the Romans came? 
ii

But now there's work, much work to be done, bypassing their tariffs on wheat and tin, placing our people in the new institutions, curbing the inrush of bordering clans and luring tutors, from Rome and Greece, to teach our youth their baffling tongue, their tricks of governance and money lore.

Panes of glass in the turf-roofed hovels of serf and bondsman in every dale!

I go to bed exhilarated, but ill at ease.

How can we persuade the Picts and Celts there's no going back to the tribe?

How can we stop the wild young zealots attacking the handful of Romans who've stayed and want to build this thing they call a state?

\section{iii}

And so, in a way, I've begun to miss them.

Despite the cold abstractions of their speech and their insufferable belief, that to advance we'd have to take Rome into our hearts, I have, from time to time, begun to miss them.

'For shit's sake Ethelbert, how can you?' I hear my hurt and angry agemates ask.

The throng of serfs, scythes in hand, hanging around all day outside my door, that's why, I say to them, that's why.

Have you not also heard them complain of empty barns and unworked fields, of bribes extracted by petty officials, posts restricted to certain bloodlines and a nasty death for those who resist? 
Did you believe an end to the Romans would do away with jealousy, greed and spite and bring improvement to the soul of man?

And now, ha - even the Druids!

When they rip mistletoe from the trees and shaking fists, harangue unlettered folk about the loose behaviour in the villages and the mad expectation, burning the youth, that life should get better with every year, I miss, in a way, an old if bitter consolation.

I miss being able to shrug and say, 'Not us, not us, the Romans are to blame'. 